\title{
Education for Democracy: A Co-constructivist Perspective
}

\author{
STEVEN BERMAN \\ JAMIE WANDERMAN \\ ERVIN BRIONES \\ LILIANA WOLF \\ WILLIAM KURTINES \\ Florida International University
}

\begin{abstract}
SUMMARY.-En el presente artículo describimos el papel que la educación ha de desempeñar en el proceso de mejora de la calidad de vida en el mundo moderno. El enfoque específico de este artículo enfatiza el papel que la educación debe desempeñar para promover la evolución de las formas de vida democráticas como un medio para mejorar la calidad de la vida tanto personal como colectiva e institucional.

La calidad de vida, al menos en lo concerniente a la conducta orientada a fines, supone elegir los valores y alcanzar con éxito los objetivos de la vida. Esto último, está relacionado con la utilización del pensamiento y la discusión crítica para realizar elecciones vitales de tipo individual y colectivo. Lo cual, a su vez, tiene que ver con la institucionalización del ideal democrático. En este sentido, el enfoque principal de nuestro trabajo aplicado trata de promover la evolución de las formas de vida democráticas como un medio para mejorar la calidad de vida en los niveles personal, interpersonal e institucional.
\end{abstract}

In this article we describe the role that education has to play in enhancing the quality of life in the modern world. More specifically, the focus of this article will be on the role that education has to play in fostering the evolution of democratic forms of life as a means for enhancing the quality of individual, interpersonal, and institutional life.

The co-constructivist perspective that is at the core of our view of education draws on both the social constructivist (Berger \& Luckman, 1967; Gergen, 1985; Habermas, 1979 ) and the socio-evolutionary tradition (Campbell, 1975; Hogan \& Bush, 1984; Waddington, 1967). According to our co-constructivist perspective, human beings have the capacity for intentional, self-directed, goal-oriented behavior. In this sense, a co-constructivist perspective is one that considers human beings to have the capacity and responsibility for the creation of their reality. This perspective emphasizes the «co»-constructed nature of reality, i.e. the subjective construction and intersubjective coconstruction of human reality. Our co-constructivist perspective grew out of our interest in broadening our understanding of the changing individual in a changing world. We have sought to extend this work by focusing on the human capacity to understand and 
control the forces that influence personal and historical change and the responsibility for the quality of life that accompanies this capacity.

The quality of life, at least with respect to human goal oriented behavior, is related to successfully choosing and fulfilling life goals and values. Successfully choosing and fulfilling life goals and values is related to the use of critical thinking and discussion in making individual and collective life choices, which is itself related to the institutionalization of the democratic ideal. The trust of our applied work has thus been on fostering the evolution of democratic forms of life as a means for enhancing the quality of life at the individual, interpersonal and institutional levels.

We view the aims or goals of education themselves as human constructions and coconstructions that have evolved and continue to evolve as part of the social evolution of the species. Drawing on our co-constructivist socio-evolutionary perspective we articulate a perspective on educational philosophy and educational practice rooted in the view that educational goals and values do (and should) change and evolve as culture and society change and evolve. We use this perspective as a springboard for articulating a framework for conceptualizing the role of education in the modern world. It is our view that the profound social evolutionary changes that occurred with the historical emergence o democratic institutions require equally profound changes in the goals and values that define modern education. More specifically, we propose that the goals and values that define modern education have to be expanded to address the enormous challenge of the realization of the potential opened up by the evolution of democratic forms of life. However, before we proceed any further with these ideas, we would like to make some statements about the history of our more general philosophy of education.

\section{EDUCATION FOR CONTENT AND COMPETENCE}

In the history of Western educational philosophy, two views have emerged with respect to how much education is a socialization process -traditionalism and progressivism. The traditionalist view dominated Western education up to the Modern Age. This view tended to emphasize the role of education in preserving and transmitting knowledge, i.e., education as socialization. The traditionalist view drew upon the educational philosophies of thinkers of the classical period such as Plato and Aristotle and the interpretations of the works of the classical philosophers by Augustine and Aquinas during the Middle Ages. Essential to traditionalist theories of education was the view, taken from the classical philosophers, that knowledge was a fixed and ordered body of information and the student the receptor of this knowledge. In this traditionalist view education was largely conceived of as communicating or transmitting this body of knowledge to the student. In terms of educational practices, this view emphasized formal instruction, drill, memorization, and practice -mostly in the area of basic literacy and vocational skills. Education beyond training was largely confined to a selected few, who were educated in the general range of knowledge. The traditionalist view, with its emphasis on education as socialization, predominated Western education until it was challenged by Rousseau in the eighteenth century. Rousseau emphasized the necessity of making education compatible with the natural development of the student. Knowledge is not to be imposed externally on the student but allowed to develop naturally from within. Education, Rousseau 
argued, should be student centered. Stundent centered education (which has come to be called the progressive view of education) eventually came to occupy a central place in modern educational philosophy.

John Dewey carried Rousseau's critique of the traditionalists' view even further by challenging the very notion that knowledge was a fixed and ordered body of information. Dewey believed that the sheer mass of knowledge produced by the scientific and industrial revolutions foreclosed on any realistic attempt to use education as the means for transmitting knowledge from one generation to the next. Rather, Dewey argued, educational practices must concentrate primarily on training the student about knowledge. Such training, according to Dewey, eventually allows members of the new generation selectively to acquire knowledge already possessed by others and, more importantly, to generate new knowledge. In Dewey's view, progressive education required more than socialization (i.e., education for content) -it required education for competence.

This progressive view of education has had a tremendous impact not only in the United States but throughout much of the modern world. The progressive view of education, however, has not been without problems -not the least of which is a tendency to emphasize fostering the development of competence at the expense of content. As R. S. Peters (cited in Bowen \& Hobson, 1974) has noted:

\begin{abstract}
«There have ben many like Dewey who have attacked the notion that education consists in the transmission of a body of knowledge. Stress is placed on critical thinking, individual experimentation and problem-solving. I have witnessed lessons in American schools where this view was slavishly applied: the teacher used poems purely to encourage «critical thinking»; history was used, as it were, to provide riders for problem-solving. The notion that poetry should be listened to, or that one has to be, to a certain extent, a historian in order to understand a historical problem, was an alien one. The emphasis on «critical thinking» was enough, perhaps, when bodies of knowledge were handed on without being made to hand on also the public procedures by means of which they had been accumulated, criticized, and revised. But it is equally absurd to foster an abstract skill called «critical thinking» without handing on anything concrete to be critical about. For there are as many brands of «critical thinking» as there are disciplines, and in the various disciplines such as history, science, and philosophy, there is a great deal to be known before the peculiar nature of the problem is grasped» (cited in Bowen \& Hobson, 1974, p. 374).
\end{abstract}

There has thus emerged in modern educational philosophy a tradition, of which Peters' work is representative, that seeks to reconcile the traditionalist and progressivist views of education. This tradition recognizes the strengths and weaknesses of both views and seeks to establish a middle-of-the-road position. We consider the view of education that we offer in this paper to build on this emerging tradition in modern educational philosophy.

\title{
MOVING FROM THEORY TO PRACTICE
}

The theoretical claim that the evolution of democratic institutions has opened up the possibility or all human beings to participate in the collective decision making processes that affect the quality of their lives provides part of the background that plays an important role in our move from theory to practice. That is, the theoretical claim that human 
beings have the capacity to shape and influence the quality of their inividual and collective lives raises the practical question of whether fostering the further evolution of democratic forms of life is desirable and the question of the means by which such a goal might be achieved. Our belief that democratic forms of life are more desirable than nondemocratic forms of life provides the foundation or ground work for out philosophical perspective. We further believe that education can (and should) play a major role in fostering democratic forms of life. In the subsequent section we will outline out view of the role that individuals and institutions play in preserving and promoting democracy, and in the final section we will focus on the role of education.

\section{EDUCATION AND THE FUTURE OF DEMOCRACY}

Education has the potential for having a broader, more extensive influence on enhancing tha quality of life than any other social institution in the modern world. The idea that education has an important role in preserving and promoting democracy is, of cource, not new. Dewey, for example, proposed that modern education has a central role to play in preserving and promoting democracy. He thought that modern progressive education should have as its goal the development of the skills necessary for the full participation in modern democratic societies. He maintained that the only type of education that is consistent with modern democratic societies is democratic education, a system based on the assumptions of the inner worth and equal dignity of all persons. As Dewey notes in Democracy and education (1916/1966):

«Since education is a social process, and there are many kinds of societies, a criterion for educational criticism and construction implies a particular social ideal. The two points selected by which to measure the worth of a form of social life are the extent in which the interest of a group are shared by all its members, and the fullness and freedom with which it interacts with other groups. An undesirable society, in other words, is one which internally and externally sets up barriers to free intercourse and communication of experience. A society which makes provisions for participation in its good of all its members on equal terms and which secures flexible readjustment of its institutions through interaction of diferent forms of associated life is in so far democratic. Such a society must have a type of education which gives inividuals a personal interest in social relationships and control, and the habits of mind which secure social changes without introducing disorders» (p. 99).

Like Dewey, our co-constructivist perspective proposes that the goals of education must be ultimately evaluated and justified in terms of particular social items, including the democratic ideal. Our view of the role of education in preserving and promoting democracy builds on Dewey's view of education as education for democracy. However, we extend his work in a number of ways. To begin with, we extend Dewey's view of the function of the democratic ideal. In our view, the increasingly widespread growth and dissemination of democratic forms of life provide support for the view that the democratic ideal is the most useful criterion for evaluating the quality of life. This includes not only institutional forms of life, but the quality of all forms of social life. The fact that such a broad range of people from such a diverse array of cultural and historical traditions, when given a choice, seem to prefer a democratic society, demonstrates its practi- 
cal significance and value. Indeed, those who would maintain otherwise face a dificult challenge; namely, proposing an alternative ideal, standard, or criterion for evaluating the quality of social life that has demonstrated equal or greater practical significance and value under as enormous a variety of conditions.

Education thus has a role to play in fosering the use of critical competencies in specific realms of discourse. Indeed, it is our view that the issues that have emerged in such a discourse communities provide the content around which such skills can be taught. Science education, for example, cannot (should not) involve simply the teaching of a body of knowledge. On the contrary, the existing body of scientific knowledge (i.e., the current scientific consensus with respect to scientific «facts») provides the content around which the teaching and learning of the use of certain types of reasoning in problem solving and decision making (i.e., critical thinking and discussion) as practiced by the scientific community should occur. Similarly, education for citizenship can (and should) use current sociomoral-political issues as the content around which the teaching and learning of the use of critical thinking and discussion in problem solving and decision making as practiced by sociomoral-political communities.

The realization of the potential that the emergence of democratic social institutions has opened up, however, requires much more than fostering the use of critical thinking and discussion in particular discourse communities. The realization of this potential requires fostering the development and use of critical competencies independent of institutional context. Fostering the evolution of democratic forms of life involves the institutionalization of the democratic ideal in all domains of human life. Because of its potential impact on all domains of life, education has a central role to play in achieving this goal. In fostering without constraint or limitation the development and use of modes of thought and communication that are at their core democratic, education ultimately contributes to the institutionalization of the democratic ideal in all domains of human life. Thus, fostering the institutionalization of the democratic ideal is not an optional goal of education in modern societies, i.e., it is not a luxury that may or may not be included. On the contrary, fostering the development and use of critical competencies is the essential element of education for emocracy.

This, then is the core of the contribution of out co-constructivist perspective to the aims or goals of education. The goals of education have to be expanded to include the goal of fostering the evolution of democratic forms of life by means of fostering the development and use of critical competencies in problem solving and decision making in all domains of human life. This view also has direct implications for educational practice. Educational practices that are democratic themselves foster in students the use of critical thinking and discussion in problem solving and decision making. That is, specialized institutions of teaching and learning should not only seek to foster the use of democratic practices, they should be democratic, i.e., they should practice what they preach. The view that educational practices should be democratic, we would sugest, applies to all levels of education as far as practical. The view that educational practices should be democratic, however, is central to adult education. Education that fosters the use of critical thinking and discussion in problem solving and decision maing is in our view not only education for democracy it is also democratic education.

Education thus has a central role to play in shaping and influencing the quality of life in the modern world. Fostering the evolution o democratic forms of life contributes 
to the realization of the potential opened up by the social evolution of democratic institutions. The potential opened up by the evolution of democratic forms of life is that of enhancing the quality of life by enlarging and expanding the boundaries of our cultural and historical horizon to include the goal or ideal of providing the opportunity for all human beings to participate in the decision making processes that affect the quality of their lives.

Although fostering the evolution of democratic forms of life is a long term goal, it is a goal that can be realized by educational practices aimed at having an impact on the actual day-to-day experiences of real human beings. This means that the goal of education for democracy is to foster the development and use of critical competencies in individual problem solving and decision making in the personal domain. It also means that the goal of education for democracy is to foster the development and use of critical competencies in group problem solving and decision making in the interpersonal domain. We thus consider education for democracy to include fostering the development and use of critical thinking and discussion in both the personal and interpersonal domains.

In the personal domain, education for democracy has as one of its goals fostering the development and use of critical thinking and critical discussion in personal problem solving and decision making. We consider teaching and learning that seeks to foster, in individuals, the use of practices that are at their core democratic an essential element of education for democracy. This is because we view social systems as the collective coconstructions of the individuals who comprise system. Social systems have an objective existence, however, they cannot exist independent of the individuals who make up the systems. Social systems are ultimately the collective co-constructions of the individuals who make up the systems. Consequently, fostering in individuals the use of practices that are ar their core democratic also facilitates the institutionalization of the use of the same practices. The use or practice of critical thinking and discussion provides a link between individual and group problem solving and decision making. To the degree that individual members of social institutions value and use practices that are democratic, the institutions these individuals are members of approximate the democratic ideal.

In the interpersonal domain, education for democracy also has as one of its goals fostering the development and use of critical competencies in close interpersonal relationships such as family, friends, peers, etc. These close interpersonal relations, like institutional relations, are defined by shared goals and values. Like institutional relations, close interpersonal relations can be more or less open and democratic. Moreover, the goals and values that define our close interpersonal relations serve as basic building blocks for our institutional relations. The practices that define our personal relations carry over to our institutional relations. Thus, one aim of education for democracy should be to foster the development and use of critical thinking and discussion in problem solving and decision making in close interpersonal relations. The use of critical competencies in problem solving and decision making in close interpersonal relations foster relations that approximate the democratic ideal, namely, relations that are open and democratic.

Finally, in the interpersonal domain, education for democracy should be also aimed at fostering the development and use critical thinking and discussin in problem solving and decision making in institutional relations. That is, it should be aimed at individuals as citizens in and members of social institutions, societies, and cultures. Education for 
democracy shoul foster institutional relations that approximate the democratic ideal, namely, relations that are open and democratic. Close interpersonal and institutional relations are open and democratic to the extent that they approximate in practice the democratic ideal. This means that in open and democratic relations, regardless of type, all participants have the freedom and equality of opportunity to participate in collective decision making processes. It also means that in the co-construction of shared mutual goals and values no goal or value is exempt from open discussion and critical examination. Finally, it also means that open and democratic relations are non-strategic. That is, open and democratic relations are free from the use of force, power, intimidation, manipulation, and deception.

\section{Fostering THE USE OF CRITICAL THINKING AND DISCUSSION}

In our applied work we have begun to explore the use of educational interventions to foster the use of critical thinking and discussion in individuals. Although we view educational practices that foster the use of critical skills in individuals as ultimately fostering the evolution of democratic forms of life, our initial efforts in the area of applied research focused on testing the effectiveness of the interventions in individuals, using (or adapting for use), as much as possible, methods, measures, and procedures that we had developed as part of our theoretical research. In this chapter we will describe some of our initial efforts to develop a program of applied research and discuss some empirical evidence to support of our claim that it is possible to foster the use of critical skills in individuals.

\section{PROJECT RESOLVE}

In developing our educational inteventions, one of our claims has been to refine educational interventions for teaching and learning the use of critical skills, the effectiveness of which can be empirically tested. These educational interventions have been developed as part of an ongoing research project, Project Resolve. Project Resolve refers to a series of research studies aimed at the development of an intervention modality for fostering the use of critical thinking and discussion skills. We adopted the name Project Resolve for our work in this area because we have found the context conflict resolution to be a very usefull framework for fostering the use of critical skills.

The intervention modality that we will be decribing was developed for use with adolescents and adults. We developed our intervention for use with this population because our work on the development of psychosocial competencies suggested that the development of a full range of psychosocial competencies, including critical thinking and discussion, does not occur prior to adolescence. We would point out, however, that in developing an intervention for working with adult populations we do not mean to imply that educational interventions cannot or should not be developed for use with younger age populations. However, such interventions would necessarily have to focus on the development of competencies as well as the use of competencies. In order to set limits on the range of our applied work and simplify our initial research objectives, we decided 
to focus on fostering the use of modes of critical thinking and discussion in individuals who already have available a full range of psychosocial competencies. Our intervention modality is thus not designed to foster the development of critical competence, but to foster the use of such competence.

In addition, because we were interested in developing an interention modality that could be subjected to empirical tests, one of our aims was to develop a relatively simple format for our modality. The educational modality that we selected for use as an intervention was that of the training exercise. We decided to use training exercises, in part, because training exercises can be readily adapted to a variety of formats. For our current work we have developed our three basic formats for our training exercises: workshop, self-administered, and group administered.

\section{The Developing AND ApPlying CRitical Skills (DACS) EXercises}

The training exercises that we developed as part of Project Resolve are designed to promote the use of critical thinking and discussion resolving normative conflict. We have called the intervention modality the Developing and Applying Critical Skills Exercises (DACS Exercises for short). The core of the DACS Exercises for all three formats is essentially the same. The core of the DACS Exercises consists of an ordered sequence of «lessons» and accompanying "practical exercises» presented in ordinary language. The focus of the lessons and exercises is on the use of critical skills. Because we were interested in fostering the use of critical thinking and discussion in the resolution of conflicting normative claims, the content of the lessons is organized around the resolution of «value» conflict. The lessons begin with basic concepts and move to more advanced application of the concepts.

All three formats (workshop, self-administered, group-administered) that we have developed for the DACS Exercises consist of ten lessons and practical exercises for each lesson. The lessons describe the basic concepts and are designed to encourage the individual to apply these concepts. The lessons aim to foster the use of critical skills in the both the personal and interpersonal domains. The lessons aim at fostering the use of modes of critical thinking and critical discussion in the personal problem solving and decision making. In addition, they are aimed at fostering the use of critical competencies in close interpersonal relations -family, frineds, peers, etc. The use of critical modes of thouht and discussion, we noted, fosters close interpersonal relations that approximate the democratic ideal, namely, relations that are open and democratic. Finally, the lessons are aimed at fostering the use of modes of critical thinking and critical discussions in individuals as citizens in and members of democratic societies. The use of critical modes of thought and discussion also foesters institutional relations that are open and democratic. Close interpersonal and institutional relations, we observed, are open and democratic to the extent that they approximate in practice the democratic ideal.

\section{USING THE GROUP ADMINISTERED DACS EXERCISES}

In our applied work we have begun to explore the use of educational interventions to foster the use of critical thinking and discussion in individuals. A research study 
(Dancs, 1987) was conducted to test the effectiveness of the group administered DACS exercices in increasing the use of critical communication. It was found that subject in the experimental training group condition used significantly more critical discussion in posttest and follow-up, than their control group counter-parts. In fact, in the control group, critical discussion was practically non-existent. In addition, Pollard (1992) reported that subjects who engage in the use of critical discussion are more likely to constructively resolve sociomoral conflicts.

We recognize the limitations of our initial effort in applied research, but we consider our work to provide tentative support for our claim that it is possible to foster the use of critical thinking and discussion. Currently we are expanding the versatility of the DACS. The original DACS was aimed at the value of using critical skills in conflict resolution. New versions are now under construction to apply the use of critical toward making life choices and improving relationships. Seeking to address the larger issue of whether such teaching and learning generalizes to everyday life and thus contributes to fostering the evolution of democratic forms of life (and thereby improving the overall quality of life) is one of the long range objectives of our program of applied research.

The social evolution of democratic institutions transformed the quality of life in the modern world and opened up the possibility of enlarging and enriching our cultural and historical horizon by fostering the global evolution of democratic forms of life. The spread of democratic institutions, to the extent it has ocurred, was the product of a lengthy process of social evolutionary change. Moreover, the process is not only not complete, but it is necessarily an ongoing one. The evolution of democratic forms of life, however, has the potential for providing the opportunity for all human beings to participate in decision making processes that affect the quality of their lives. Thus, to approximate in practice the democratic ideal on a global scale is a goal that is not only enormously challenging, but also imminently worthy of the protracted commitment necessary to achieve such a goal. Education or democracy, consequently, is not education for today. It is not even education for tomorrow. It is education for the day after tomorrow. It is education for the future.

\section{REFERENCES}

BERger, P. L. \& LuCKMAn, T. (1967). The social construction of reality, Doubleday (Anchor Books), Nueva York.

Bowen, J. \& Hobson, P. R. (1974). Theories of education: Studies of significant innovation in Western educational thought, John Wiley \& Sons, New York.

CAMPBell, D. T. (1975). «On the conflicts between biological and social evolution and between psychology and moral tradition», American Psychologist, 30, 1103-1126.

DANCS, M. (1987). The effects of training on communicative functioning during normative discussion, Unpblished Masters Thesis, Florida International University, Miami, Florida.

DEWEY, J. (1916/1966). Democracy and education: An introduction to the philosophy of education, The Free Press, New York.

GERGEN, K. J. (1985). «The social constructionist movement in modern psychology», American Psychologist, 40, 266-275. 
HABERMAS, J. (1979). Communication and the evolution of society, Beacon, Boston.

Hogan, R. \& BusCH, C. (1984), «Moral conduct as auto-interpretation». In W. KuRTINES \& J. L. GEWIRTZ (eds.). Morality, moral behavior and moral development, John Wiley \& Sons, New York, 227-240.

POLLARD, S. R. (1992). Critical communicative style as a predictor of critical communicative performance and constructive conflict resolution. Unpublished Doctoral Dissertation, Florida International University, Miami, Florida.

Waddington, C. H. (1967). The ethical animal, University of Chicago Press, Chicago, Ill. 